Dzieje Najnowsze, Rocznik LIII - 2021, 2

PL ISSN 0419-8824

\author{
Jan Stanisław Ciechanowski \\ https://orcid.org/0000-0003-3542-1991 \\ Uniwersytet Warszawski
}

\title{
Uznawanie przez Hiszpanię rządu Rzeczypospolitej Polskiej na uchodźstwie w latach 1945-1968. Historia pewnego mitu
}

\begin{abstract}
Abstrakt: W latach 1942-1943 stosunki dyplomatyczne między Polską i Hiszpanią zostały zawieszone. Po cofnięciu uznania rządowi RP w Londynie gabinet w Madrycie nie uczynił tego i w latach 1945-1968 pozostawał z polskim poselstwem w stolicy Hiszpanii (w latach 1955-1961 z dwoma) w relacjach półoficjalnych. Przedstawiciele RP nie znajdowali się na liście korpusu dyplomatycznego, za mit należy więc uznać, iż dyktatura gen. Francisco Franco utrzymywała stosunki dyplomatyczne z rządem RP na uchodźstwie.
\end{abstract}

Słowa kluczowe: Polska, Hiszpania, stosunki dyplomatyczne, rząd RP na uchodźstwie.

Abstract: In 1942-1943, diplomatic relations between Poland and Spain were suspended. After the withdrawal of recognition for the Polish government in London, the government in Madrid did not do so, and in 1945-1968 it maintained semi-official relations with the Polish legation in the Spanish capital (in 1955-1961 there were two of them). Representatives of the Republic of Poland were not on the official list of the Diplomatic Corps, so it should be considered a myth that General Francisco Franco's dictatorship maintained diplomatic relations with the Polish government-in-exile.

Keyw ords: Poland, Spain, diplomatic relations, Government of the Republic of Poland in exile.

Wizja dziejów relacji polsko-hiszpańskich XIX i XX w. w historiografii jest pełna mitów, legend i różnego rodzaju fałszów. Ponad 150 lat musiało upłynąć w Polsce, by hiszpańska historyk rozprawiła się z utrwalonym przez 
rodzimą literaturę i kinematografię mitem o niewoleniu zakonnic przez polskich żołdaków podczas oblężenia Saragossy w 1808 r. ${ }^{1}$ Nie jest to jeszcze fakt znany w naszym kraju, głównie $\mathrm{z}$ uwagi na barierę językowa, dlatego też - w oczekiwaniu na tłumaczenie odnośnych dzieł - mit dalej żyje swoim życiem ${ }^{2}$. Niemniej utrwaliła się u nas legendarna wizja hiszpańskiej wojny domowej z lat 1936-1939, także pełna zakłamań. W czasach dyktatury komunistycznej sugerowano m.in., że sanacyjna Polska masowo sprzedawała broń i amunicję rebeliantom gen. Francisco Franco ${ }^{3}$, podczas gdy w rzeczywistości dostawy na ogromną skalę były kierowane do mających czym płacić lewicowców $^{4}$. Przykłady tego rodzaju, wynikajace albo z braku podstawowych badań, albo celowo uprawianej propagandy, można by mnożyć. Polska historiografia, niejako wierna tej tradycji, dopuściła również do pojawienia się mitu, który może nie ma takiego znaczenia, ale wykrzywia w pewnym stopniu rzeczywista pozycję międzynarodową polskich rządów na emigracji w Londynie po zakończeniu II wojny światowej, nie mówiąc już o fałszywym przedstawianiu ważnego etapu relacji między Polską i Hiszpania.

W polskich opracowaniach często przyjmuje się, że hiszpańska dyktatura gen. Franco utrzymywała normalne (pełne) stosunki dyplomatyczne z rzadem RP na uchodźstwie $\mathrm{w}$ Londynie ${ }^{5}$, w wersji zaś łagodniejszej i nie tak jednoznacznej - że nie wycofała uznania rządu $\mathrm{RP}^{6}$, co przy odpowiedniej interpretacji i z zastrzeżeniami można uznać za prawdę. W 2017 r., z okazji 40. rocznicy nawiązania stosunków między tzw. PRL a Królestwem Hiszpanii, Ministerstwo Spraw Zagranicznych (MSZ) RP skonstatowało na swej oficjalnej stronie internetowej, iż „po zakończeniu II wojny światowej Hiszpania nie wycofała uznania dla emigracyjnego rządu RP w Londynie, a w Madrycie w dalszym ciagu funkcjonowała polska placówka dyplomatyczna"7. Resort

1 Zob. C. González Caizán, Por Napoleón en España. Los soldados polacos en los Sitios de Zaragoza (1808-1809), Madrid 2017; El anónimo polaco. Zaragoza en el año 1809. Fragmento de las memorias todavía no publicadas, estudio, traducción y edición C. González Caizán, Zaragoza 2012.

${ }^{2}$ Por. K. Varga, Antologia cmentarna, czyli Prezydent czyta i zachwala, „Duży Format. Magazyn reporterów”, dodatek do „Gazety Wyborczej”, 19 III 2008, nr 11 (1276), s. 3.

${ }^{3}$ S. Ajzner, Państwo polskie wobec wojny domowej w Hiszpanii 1936-1939, „Najnowsze Dzieje Polski. Materiały i Studia z Okresu 1914-1939” 1963, t. VI, s. 55-57; por. idem, Polska a wojna domowa $w$ Hiszpanii 1936-1939, Warszawa 1968, s. 45-52.

${ }^{4}$ J.S. Ciechanowski, Podwójna gra. Rzeczpospolita Polska wobec hiszpańskiej wojny domowej 1936-1939, Warszawa 2014, s. 456-560.

${ }^{5}$ Zob. np.: K. Tarka, Emigracyjna dyplomacja. Polityka zagraniczna rzadu RP na uchodźstwie 1945-1990, Warszawa 2003, s. 39, 162-164.

${ }^{6}$ Zob. np.: J. Tebinka, Dyplomacja popaździernikowa (1957-1960), w: Historia dyplomacji polskiej, t. VI: 1944/1945-1989, Warszawa 2010, s. 556; K.A. Tochman, Z ziemi obcej do Polski. Losy żotnierzy, którzy powrócili do kraju po II wojnie światowej, t. I, ZwierzyniecRzeszów-Londyn 2006, s. 211.

7 40. rocznica nawiazania stosunków dyplomatycznych z Hiszpania, 31 I 2017, oprac. Wydział Wiedzy Historycznej Biura Archiwum i Zarządzania Informacją MSZ, http://www.msz.gov. 
kompetentny w sprawach zagranicznych oparł się na ustaleniach części historyków. W literaturze przedmiotu można jednak znaleźć jednoznaczna informację, że po zakończeniu konfliktu Hiszpania nie uznawała oficjalnie polskich rządów na uchodźstwie, nie utrzymując z nimi stosunków dyplomatycznych, a Poselstwo RP w Madrycie miało charakter jedynie półoficjalny (oficioso), będąc placówką „uznaną" kurtuazyjnie i „towarzysko”.

Przyjrzyjmy się więc temu zagadnieniu bliżej. W czasie hiszpańskiej wojny domowej z lat 1936-1939 stosunki polityczne między Warszawa i Burgos były generalnie dobre. Pozytywne nastawienie dyktatury polskich niepodległościowców do rządu Hiszpanii „narodowej” pogłębiało się wraz z coraz większym stopniem kontroli sprawowanej nad hiszpańskimi rządami lewicowymi przez Związek Sowiecki. Polacy wspierali powstańców na forum Ligii Narodów i Komitetu Nieinterwencji, w ogarniętym rewolucją Madrycie udzielili ok. 400 Hiszpanom azylu, pozwolili działać w Warszawie nieoficjalnemu przedstawicielowi władz w Burgos z prawem szyfru, a już w grudniu 1937 r. poseł RP w Hiszpanii Marian Szumlakowski nawiązał pierwsze polityczne kontakty z przedstawicielami Caudillo. W kwietniu następnego roku Warszawa postanowiła uznać de iure jego rząd z chwilą zajęcia Madrytu, a w październiku uczyniono to de facto.

Hiszpańskich prawicowców z rządzącymi Polską piłsudczykami łączyły przywiazanie do niepodległości oraz negatywny stosunek do komunizmu i innych radykalnych marksistowskich projektów. Nie bez znaczenia były także echa popularności polskiej walki o wolność w XIX w. oraz skuteczne zatrzymanie marszu bolszewików na Europę Zachodnią w bitwie pod Warszawa w sierpniu 1920 r. Po obu stronach nie brakowało odniesień do roli tych położonych na rubieżach Europy państw jako bastionów cywilizacji chrześcijańskiej na wschodzie i zachodzie kontynentu. Pomimo to w okresie hiszpańskiej wojny we wzajemnych stosunkach pojawiły się także elementy negatywne. Prawica hiszpańska zapamiętała masowe dostawy uzbrojenia z Polski dla „czerwonych”. W przypadku rzekomo dużej liczby Polaków w Brygadach Międzynarodowych (ok. 4,5 tys. osób, oficjalnie druga nacja po Francuzach) nie zdawano sobie sprawy, że ok. 3/4 z nich przybyło z Francji, wielu miało obywatelstwo

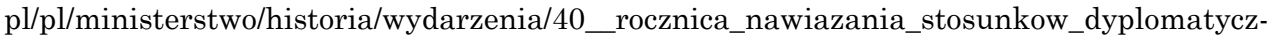
nych_z_hiszpania;jsessionid=30F86D49D9DE9061E77E6D77B87DAB83.cmsap5p (dostęp: 21 XI 2017).

${ }^{8}$ Ks. A. Liedtke, Wojenne losy biskupa chetmińskiego Stanistawa Wojciecha Okoniewskiego 1939-1944, Pelplin 1983, s. 133; T. Wyrwa, Poselstwo R.P. w Madrycie w latach 1940-1944, „Zeszyty Historyczne” 1991, z. 95, s. 71; P. Machcewicz, Emigracja w polityce międzynarodowej, Warszawa 1999, s. 218; J.S. Ciechanowski, General Anders and His Contacts With Spain, w: General Wtadystaw Anders. Soldier and Leader of the Free Poles in Exile. Papers from the Conference Organised by the Polish University Abroad London 15-16 June 2007, red. J. Pyłat, J. Ciechanowski, A. Suchcitz, London 2008, s. 194; J.S. Ciechanowski, Działalność polskiego wywiadu w Hiszpanii w czasie II wojny światowej, w: Szpiegostwo, wywiad, państwo, red. C. Taracha, t. I, Lublin 2009, s. 230, 232. 
francuskie, a w grupie ekspediowanej przez Komintern do Hiszpanii z Polski wysoki odsetek stanowili przedstawiciele mniejszości narodowych II RP (Żydzi, Ukraińcy i Białorusini). W tym wypadku Hiszpanie tradycyjnie nie odróżniali obywatelstwa od narodowości, co dla Warszawy było oczywiste. Polskie władze zresztą nie uznawały za ważne tłumaczenie tego stanu rzeczy na zewnątrz, ostro traktując brygadzistów na podstawie rodzimego prawa, które przewidywało pozbawienie obywatelstwa w przypadku służby w obcej armii czy administracji bez zezwolenia rządu RP. Te różnice w mentalności i związane z tym trudności komunikacyjne dały się także zauważyć w postaci negatywnego stosunku Hiszpanii do sojuszu Polski z Francją Frontu Ludowego, który to alians - bez względu na profil ideologiczny gabinetu w Paryżu był w tym czasie dla Warszawy głównym filarem bezpieczeństwa państwa.

Gdy wybuchła II wojna światowa w wyniku ataku Niemiec na Polskę we wrześniu 1939 r., Hiszpania opowiadała się za lokalizacją konfliktu, co było przeciwstawne polskim interesom ${ }^{9}$. Pismo z 4 września ministra spraw zagranicznych płk. Juana Beigbedera Atienzy, stanowiące odpowiedź na notyfikację stanu wojny, władze RP traktowały jako oficjalne uznanie Polski za stronę wojująca ${ }^{10}$. Pomimo utrzymującej się wzajemnej sympatii, szczególnie po rozpoczęciu inwazji sowieckiej 17 września i w wyniku rozgoryczenia z powodu zawarcia przez Hitlera de facto sojuszu ze Stalinem, co w Madrycie wywołało fatalne wrażenie, sprawa polska była dla Hiszpanów zagadnieniem drugorzędnym, funkcją o wiele ważniejszych interesów. Przypominało to w pewnym sensie stosunek Polski do ogarniętej bratobójczą wojną Hiszpanii lat 1936-1939. Polacy skarżyli się na proniemiecką i pronazistowską propagandę w większości hiszpańskich mediów, aczkolwiek polscy dyplomaci zdawali sobie sprawę, że Hiszpanie starają się prowadzić politykę niezależna, a wśród wybitnych postaci reżimu znajdowali się tacy, którzy nie byli zwolennikami Niemiec hitlerowskich. Pomimo nacisków Berlina Madryt nie zlikwidował Poselstwa RP, dalej utrzymując stosunki dyplomatyczne z Polska, choć poseł Luis de Pedroso y Madan, hrabia San Esteban de Cañongo, nie został wysłany do Paryża albo Angers, gdzie miał siedzibę rząd RP na uchodźstwie, odtwarzający w tym czasie polską armię u boku francuskiej sojuszniczki ${ }^{11}$. Latem

${ }_{9}$ Por. J.M. Doussinague, España tenía razón (1939-1945), Madrid 1949, s. 12-13, 361.

${ }^{10}$ Uniwersytet Warszawski, Wydział „Artes Liberales”, Kolekcja Mariana Szumlakowskiego (dalej: KMS), nota werbalna Poselstwa RP w Madrycie (dalej: PRPM) do hiszpańskiego MSZ (Ministerio de Asuntos Exteriores - MAE), Madrid 3 IV 1942; Archivo General del Ministerio de Asuntos Exteriores w Madrycie (dalej: AGMAE), Archivo Renovado, leg. R. 2221, exp. 20, Beigbeder do Szumlakowskiego, Burgos, 4 IX 1939 (cytowana w tym opracowaniu dokumentacja AGMAE przechowywana jest obecnie w Archivo General de la Administración w Alcalá de Henares); por. R. Serrano Suñer, Entre el silencio y la propaganda, la Historia como fue. Memorias, Barcelona 1977, s. 266.

${ }^{11}$ Hiszpański arystokrata został odwołany z funkcji posła w Polsce 28 VI 1940 r. Korespondencja: AGMAE, Personal, leg. P. 293, exp. 21886; J.S. Ciechanowski, Pedroso y Madan, Luis de, w: Diccionario Biográfico Español, t. XL, Madrid 2010, s. 478. Hiszpania nie 
1940 r., gdy Francja została pokonana niepodziewanie szybko, pozycję sprawy polskiej pogarszało powszechne przekonanie o wielkiej potędze III Rzeszy i dużym prawdopodobieństwie wygrania przez nią wojny, które udzieliło się nie tylko na Półwyspie Iberyjskim. Już 13 czerwca Hiszpania ogłosiła, że wobec przystapienia Włoch do konfliktu posiadać będzie odtąd status państwa niewojującego (no beligerante), co oznaczało porzucenie ścisłej neutralności. Po upadku Francji stosunki polsko-hiszpańskie przestały być symboliczne w związku z masowym napływem na półwysep polskich uchodźców, w tym wojskowych, którzy podczas kampanii francuskiej nie zdążyli na czas lub nie chcieli ewakuować się do Wielkiej Brytanii. Początkowo wielu Polakom udało się uzyskać odpowiednie wizy i przejechać legalnie przez Hiszpanię, wkrótce jednak zdecydowana większość wojskowych i cywilów przekraczała granicę francusko-hiszpańską nielegalnie (głównie z uwagi na obostrzenia w samej Francji dotyczące jej opuszczenia) i była umieszczana w więzieniach, a mężczyźni po pewnym czasie (na ogół po miesiącu) w obozie internowania w Miranda de Ebro.

Od zakończenia kampanii polskiej Niemcy domagali się zamknięcia placówek dyplomatycznych i konsularnych RP w Hiszpanii oraz położenia kresu prowadzonej pod ich przykryciem działalności wywiadowczej i ewakuacyjnej. Informowali władze w Madrycie m.in. o wykorzystywaniu przez Polaków podrobionych paszportów oraz fałszowaniu pieczątek hiszpańskiej policji ${ }^{12}$. Z kolei Brytyjczycy naciskali Hiszpanów, próbując ich przekonać do konieczności utrzymania Poselstwa RP oraz innych placówek okupowanych państw alianckich. Do poważnego pogorszenia polsko-hiszpańskich relacji doszło w październiku 1940 r., kiedy ostatnie dni pełnił swą funkcję życzliwy Polsce szef dyplomacji Beigbeder, a apogeum swoich wpływów osiagał szwagier gen. Franco, Ramón Serrano Suñer, dotąd szef resortu spraw wewnętrznych, a od 17 października nowy minister spraw zagranicznych. Na początku tego miesiąca kierowana przez falangistę José Maríę Finata y Escrivá de Romaní, hrabiego Mayalde, Generalna Dyrekcja Bezpieczeństwa (Dirección General de Seguridad - DGS) doprowadziła do przetrzymania przez kilka godzin pod strażą w Saragossie Ignacego Jana Paderewskiego, który przejeżdżał przez Hiszpanię w drodze

wysłała także swojego przedstawiciela do Londynu. W Warszawie na czele przedstawicielstwa interesów hiszpańskich stał Casimiro Granzow de la Cerda, książę Parcent. Zob. Duque de Parcent, El drama de Varsovia 1939-1944, Madrid 1946; Książę de Parcent, Casimiro Florencio Granzow de la Cerda, Dramat Warszawy 1939-1945, tłum. i oprac. M. Nalewajko, Warszawa 2016; AGMAE, leg. P. 287, exp. 21765; ibidem, leg. R. 3510, exp. 7, Nuestras relaciones con Polonia desde 1936-1946, [b.m.d.; prawdopodobnie 1946].

12 Politisches Archiv des Auswärtigen Amts w Berlinie (dalej: PA AA), Akten der Auslandsvertretungen des Deutschen Reiches (bis 1945), Botschaft Madrid 1851-1945 (dalej: RAV Madrid), Bestell-Nr. 796, memorandum Ambasady Niemiec w Madrycie (dalej: ANM) do MAE, Madrid, 31 I 1942; ibidem, nota werbalna ANM do MAE, Madrid, 11 II 1942; ibidem, notatka ANM, [b.m.] 4 III 1942. Nie zawsze przedstawiane przez Niemców informacje były dokładne. 
do Portugalii i Stanów Zjednoczonych Ameryki. Posłowi Szumlakowskiemu udało się incydent wyjaśnić i załagodzić sytuację ${ }^{13}$. Niedługo potem władze hiszpańskie dopuściły się jednak ciężkiego naruszenia zwyczajów międzynarodowych. Aresztowano czterech polskich kurierów dyplomatycznych, w tym byłego ministra skarbu i ważna postać Polski przedwrześniowej, Ignacego Matuszewskiego. 14 października został on zatrzymany na granicy w Portbou, pomimo posiadania paszportu dyplomatycznego oraz hiszpańskiej wizy wystawionej w Vichy. Przetrzymywany był w DGS w Madrycie w towarzystwie zwykłych przestępców, a 22 tego miesiąca zabrano mu siłą przewożona przez niego pocztę dyplomatyczna, podobnie jak innej aresztowanej polskiej kurierce ${ }^{14}$. Był to ostatni dzień wizyty szefa niemieckiej policji, SS i gestapo Heinricha Himmlera w Madrycie, a kopie przynajmniej części korespondencji z przesyłek trafiły do rąk hitlerowskich, czego potwierdzenie znalazłem $\mathrm{w}$ berlińskim archiwum niemieckiego $\mathrm{MSZ}^{15}$. Polaków ostatecznie zwolniono, ale pocztę udało się odzyskać jedynie częściowo ${ }^{16}$. 9 III $1941 \mathrm{r}$. władze hiszpańskie aresztowały ppor. Karola Orłowskiego, szefa nielegalnej ewakuacji w Madrycie, w czasie wojny domowej walczacego w szeregach karlistów, skoligaconego z miejscową arystokracją. Przesiedział on w więzieniu siedem tygodni, po czym zwolniono go i zmuszono do wyjazdu z Hiszpanii ${ }^{17}$. W rezultacie 31 tego miesiaca Ministerio de Asuntos Exteriores (MAE) zagroziło

${ }^{13}$ Szerzej zob. korespondencja: KMS; Archiwum Instytutu Polskiego i Muzeum im. gen. Sikorskiego w Londynie (dalej: AIPMS), Kolekcja Jana Szembeka (dalej: KJSz), KOL. 85/1, Szembek do J. Zembrzuskiego, Estoril, 9 X 1940; M. Szumlakowski, Przed 12-tu laty. Ignacy Paderewski przejazdem w Hiszpanii, „Ostatnie Wiadomości”, (Mannheim) 2 VII 1952; E.S., Declaraciones del último ministro de Polonia en España, „Semana”, (Madrid) 4 XII 1945, s. 3-4; Ks. A. Liedtke, Wojenne losy..., s. 67-68; Protokoły posiedzeń Rady Ministrów Rzeczypospolitej Polskiej, red. nauk. M. Zgórniak, oprac. W. Rojek przy współpr. A. Suchcitza, t. II: Czerwiec 1940 - czerwiec 1941, Kraków 1995, s. 147; M.M. Drozdowski, Ignacy Jan Paderewski. Zarys biografii politycznej, wyd. 3 popr. i rozsz., Warszawa 1986, s. 249-250; H. Lisiak, Paderewski. Od Kurytówki po Arlington, Poznań 1992, s. 188-189; [A. Strakacz], Paderewski as I Knew Him. From the Diary of Aniela Strakacz, tłum. H. Chybowska, New Brunswick 1949, s. 290-299; M. Perkowska-Waszek, Ignacy Jan Paderewski o sobie. Zarys biografii wzbogacony listami artysty, Tarnów-Kaśna Dolna 2004, s. 71.

${ }^{14}$ Korespondencja: KMS; por. E. Wittlin Lipton, From One Day to Another. A Fashion Reportage in a Period of Conflict, Madrid 2011, s. 196.

15 PA AA, RAV Madrid, 797, płk dypl. F. Mally do Szumlakowskiego, Lizbona, 14 X 1940.

${ }^{16}$ Korespondencja: KMS.

${ }^{17}$ AIPMS, Sztab Naczelnego Wodza i Ministerstwo Spraw Wojskowych/ Ministerstwo Obrony Narodowej, 1939-1948 (1948-1990 na uchodźstwie), Biuro Ogólno-Organizacyjne MON, A.XII.4/169, Referat w sprawie usunięcia b. Posła w Madrycie M. Szumlakowskiego z Hiszpanii, Londyn, 13 XI 1942; ibidem, notatka, [b.m. 1942]; ibidem, Dokumenty cywilnych urzędów rządowych, 1919-1991, Poselstwo RP w Madrycie, Hiszpania 1932-1968 (dalej: PM), A.45.474/20, Orłowski do Szumlakowskiego, Madryt, 21 V 1941; J.S. Ciechanowski, Polscy ochotnicy po stronie narodowej w czasie hiszpańskiej wojny domowej (1936-1939), w: Studia polsko-hiszpańskie. Wiek XX, red. J. Kieniewicz, Warszawa 2004, s. $143-145$. 
w nocie werbalnej Poselstwu RP zaprzestaniem uznawania go ze względu na podejrzenie, iż placówka dostarczała swoim obywatelom fałszywe paszporty portugalskie, co zostało kategorycznie zdementowane przez polską misję. Zwróciła się ona o dowody, których jej nie przedstawiono ${ }^{18}$. W późniejszym okresie Szumlakowski stwierdzał, że od 1941 r. misje państw „okupowanych przez wroga w konsekwencji wojny” zaczęły być traktowane przez hiszpańskie MSZ „gorzej” niż pozostałe ${ }^{19}$.

W tym czasie stało się widoczne znaczące osłabienie pozycji Polaków w Hiszpanii. Jednakże rzadko spotykali się oni z przejawami wrogości czy niechęci. Jeżeli jakiekolwiek incydenty miały w ogóle miejsce, dotyczyły osób, które manifestowały przywiązanie do przyjaźni hiszpańsko-niemieckiej i wdzięczność za pomoc udzieloną przez III Rzeszą w czasie wojny domowej. Przejawiło się to m.in. w enuncjacjach kilku urzędników Ministerstwa Armii albo z DGS o tym, że Polska już nie istnieje. Często jednak Polacy mogli liczyć na pozytywne i życzliwe nastawienie ze strony innych funkcjonariuszy hiszpańskiego reżimu. Nawet wśród dygnitarzy pronazistowskiej i proniemieckiej Falangi można było spotkać się z okazywanym Polakom szacunkiem ${ }^{20}$. Należeli oni do tych okupowanych aliantów, którzy nie mieli żadnych instrumentów nacisku na Hiszpanów, jak np. w przypadku Belgów, co powoduje, że sprawa polska jest dobrym probierzem przy badaniu meandrów hiszpańskiej neutralności podczas wojny.

Sytuacja Polaków w Hiszpanii pogorszyła się jeszcze bardziej w wyniku ataku Niemiec nazistowskich na Związek Sowiecki. Ich notowania w hiszpańskim establishmencie mocno spadły, gdy rząd RP został niejako zmuszony przez Wielką Brytanię do podpisania z Sowietami tzw. układu Sikorski-Majski. Polska stała się dla Madrytu nie państwem poszukującym swojego miejsca w ramach wysiłku wojennego przeciwko Niemcom i ratującym tysiące swoich obywateli z ,sowieckiego raju”, jak to na ogół widzi się z polskiej perspektywy, ale formalnym sojusznikiem politycznym i wojskowym ZSRS. Armię Polską tamże oraz hiszpańską Niebieską Dywizję tworzono w tym samym mniej więcej czasie i nie można było wykluczyć bezpośredniego starcia zbrojnego między nimi na froncie wschodnim. Był to czas silnego nacisku Niemiec, by Hiszpania przystapiła do wojny. Berlin wyrażał daleko idące rozczarowanie z powodu braku pozytywnej decyzji Madrytu w sprawie ataku na Gibraltar. Z kolei Hiszpanie długo obawiali się niemieckiej inwazji ${ }^{21}$.

18 KMS, nota werbalna MAE do PRPM, Madrid, 31 III 1941; ibidem, memorandum PRPM do MAE, [b.m.d.]; AGMAE, leg. R. 2221, exp. 20, nota werbalna PRPM do MAE, Madrid, 28 II 1942.

${ }^{19} \mathrm{KMS}$, Szumlakowski do Serrano Suñera, [b.m.d.].

${ }^{20}$ Korespondencja: ibidem; por. J.M. Doussinague, op. cit., s. 13; C.J.H. Hayes, Wartime Mission in Spain 1942-1945, New York 1946, s. 43-45.

${ }^{21}$ Szerzej zob. B. Kaczorowski, Churchill i Franco. Hiszpania w polityce Wielkiej Brytanii w okresie drugiej wojny światowej, Warszawa 2014. 
Nie ulega najmniejszej wątpliwości, że do pierwszej połowy 1942 r. Polska i Hiszpania utrzymywały regularne stosunki dyplomatyczne. Na początku tego roku władze w Madrycie, naciskane przez Niemców, uległy presji i kierowane przez tracacego coraz bardziej polityczne wpływy Serrano Suñera hiszpańskie MSZ zażądało w nocie werbalnej z 21 I 1942 r. zamknięcia biur poselstwa i konsulatów RP. Jako powód podawano „nienormalne” funkcjonowanie służb podległych placówce dyplomatycznej, działalność niezgodna ze zwyczajami dyplomatycznymi i „aktualnymi międzynarodowymi okolicznościami politycznymi”, szczególnie w postaci wystawiania paszportów niezgodnych z rzeczywistym stanem ${ }^{22}$. Głównym powodem tej decyzji były motywy polityczne, ale nie ulega wątpliwości, że nieskoordynowana działalność w Hiszpanii licznych, niezależnych w praktyce od poselstwa, powstałych po upadku Francji polskich agend ewakuacyjnych i wywiadowczych walnie się do tego przyczyniła. Chodziło przede wszystkim o prowadzenie nielegalnej ewakuacji polskich wojskowych przez Hiszpanię z Francji do Wielkiej Brytanii. Największe wzburzenie miejscowych władz wywołało nieudolne podrabianie przez kierownictwo ewakuacji hiszpańskich wiz, na co bezskutecznie zwracał uwagę Londynowi poseł RP Szumlakowski. Nie bez znaczenia były także działalność szpiegowska i używanie w poselstwie tajnego nadajnika radiowego.

Początkowo polscy dyplomaci uważali, że w nocie MAE w praktyce chodziło o likwidację placówek RP w Hiszpanii ${ }^{23}$. Już jednak 22 stycznia życzliwy Polsce p.o. podsekretarza stanu w MSZ José Pan de Soraluce y Español wyjaśniał Szumlakowskiemu, że nie pisano o likwidacji poselstwa, jedynie o zaniechaniu urzędowania ${ }^{24}$. Rozwiązanie wybrane przez Hiszpanów było dość kuriozalne, aczkolwiek pozwalało na twierdzenie wobec Niemców, że dokonano zamknięcia biur poselstwa i innych polskich placówek, jednocześnie zaś można było tłumaczyć aliantom, iż placówka wcale nie została zlikwidowana.

Szumlakowski rozpoczął serię interwencji, by decyzję MAE cofnięto. Poselstwo RP oraz polscy dyplomaci znaleźli się - podobnie jak reprezentanci innych państw okupowanych - na wydanej w lutym 1942 r. nowej liście akredytowanego w Madrycie Korpusu Dyplomatycznego. Placówka oficjalnie otrzymała tę publikację MAE 16 tego miesiaca ${ }^{25}$. Tymczasem jednak 26 lutego poselstwu odebrano większą część przywilejów dyplomatycznych ${ }^{26}$. $\mathrm{Na}$ styczniową hiszpańską notę werbalną Szumlakowski odpowiedział dopiero

\footnotetext{
${ }^{22}$ AGMAE, leg. R. 2221, exp. 20, nota MAE do PRPM, Madrid, 21 I 1942.

${ }^{23}$ KMS, projekt noty werbalnej PRPM do MAE, Madrid, III 1942.

${ }^{24}$ Korespondencja: AIPMS, Dokumenty cywilnych urzędów rządowych, 1919-1991, Ministerstwo Spraw Wewnętrznych (dalej: MSW), A.9.VI.10/1.

${ }^{25}$ Lista del Cuerpo Diplomático, Madrid 1942, s. 5, 12, 62; KMS, projekt memorandum PRPM do gen. Jordany, [b.m.d.]; ibidem, nota werbalna PRPM do MAE, Madrid, 3 IV 1942.

${ }^{26}$ AGMAE, leg. R. 1771, exp. 62, podsekretarz stanu w MSZ do komisarza ds. paliw płynnych, dyrektora generalnego ds. ceł, podsekretarza stanu w Ministerstwie Finansów, gubernatora cywilnego Madrytu, Madrid, 26 II 1942.
} 
28 lutego. Ubolewano, iż tak ważne zagadnienie, jak zamknięcie biur przedstawicielstwa dyplomatycznego oraz wszystkich konsulatów, komunikowano w oparciu o ,jednostronne i mało sprecyzowane oskarżenia”27. Również i tym razem poselstwo odpowiedzi nie otrzymało ${ }^{28}$.

$\mathrm{Na}$ początku marca Serrano Suñer w rozmowie z ambasadorem argentyńskim Adriánem Césarem Escobarem stwierdził, że zgadza się na pozostawienie w Hiszpanii polskiego posła. Dodał także, iż sprawę być może uda się załagodzić, aczkolwiek potrzeba pewnego uspokojenia sytuacji ${ }^{29}$. Zaraz potem doszło jednak do kolejnych zdecydowanych działań ze strony Hiszpanów. 6 III 1942 r. MAE wystosowało kolejną notę do polskiej placówki. Informowano, iż z uwagi na „specjalne okoliczności”, w których miało się znajdować polskie przedstawicielstwo RP, „można było” uważać jego misję w Hiszpanii za zakończona. Wszyscy członkowie Poselstwa RP w ciagu 14 dni winni opuścić to państwo. 13 marca w kolejnej nocie ministerstwo przedłużyło termin ich wyjazdu o kolejne $14 \mathrm{dni}^{30}$. Zwraca uwagę, że tym razem powoływano się na motywy natury politycznej, a nie kryminalnej. Chargé d'affaires ambasady Wielkiej Brytanii minister Arthur Yencken - po rozmowie z Serrano Suñerem, u którego interweniował - twierdził, iż sytuacja jest beznadziejna i że nikt z placówki RP nie może pozostać w Hiszpanii, w przypadku zaś posła - nawet $\mathrm{w}$ charakterze prywatnym ${ }^{31}$.

Wydawało się, że polscy dyplomaci podzielą los swych kolegów wypraszanych z kolejnych państw w wyniku nacisków niemieckich ${ }^{32}$. Nawet polskie MSZ pogodziło się z tym, że poselstwo w Madrycie zostało zlikwidowane ${ }^{33}$. Placówka ta nie była zresztą jedyna, która znalazła się w tak trudnej sytuacji. W tym czasie ważyły się losy misji innych państw okupowanych, jak Grecji, Jugosławii i Norwegii ${ }^{34}$. W przypadku polskiego przedstawicielstwa doszło

${ }^{27}$ KMS, nota werbalna PRPM do MAE, Madrid, 28 II 1942.

${ }^{28}$ Ibidem, memorandum PRPM do gen. Jordany, [b.m.d.].

${ }^{29}$ Ibidem, Szumlakowski do E. Raczyńskiego, kierownika MSZ, [b.m.] 2 III 1942.

${ }^{30}$ AGMAE, leg. R. 1771, exp. 62, noty werbalne MAE do PRPM, Madrid, 6 i 13 III 1942.

${ }^{31}$ KMS, Szumlakowski do Raczyńskiego, [b.m.], 1 V 1942.

${ }^{32} \mathrm{~W}$ czasie II wojny światowej polskie ambasady i poselstwa zostały oficjalnie zlikwidowane w następujących państwach w wyniku suwerennej decyzji ich rządów: Niemcy i Słowacja (wrzesień 1939 r.), Związek Sowiecki (wrzesień 1939 i kwiecień 1943 r.), Estonia i Łotwa (wrzesień-październik 1939 r.), Litwa (październik 1939 r.), Włochy (czerwiec 1940 r.), Państwo Francuskie (Francja Vichy) (wrzesień 1940 r.), Rumunia (październik-listopad 1940 r.), Węgry (grudzień 1940 - styczeń 1941 r.), Bułgaria (marzec 1941 r.), Finlandia (czerwiec 1941 - styczeń 1942 r.) oraz Japonia (październik 1941 r.). Zob. H. Batowski, Polska dyplomacja na obczyźnie 1939-1941, Kraków 1991, passim; Historia dyplomacji polskiej..., t. V: 1939-1945, red. W. Michowicz, Warszawa 1999, passim.

${ }^{33}$ KMS, Raczyński do Szumlakowskiego, Londyn, 28 IV 1942.

${ }^{34}$ Ostatecznie władze hiszpańskie utrzymały normalną działalność poselstw Danii i Holandii jako jedynych reprezentujacych państwa okupowane. KMS, Pro memoria PRPM, [b.m.d.]; ibidem, memorandum PRPM do gen. Jordany i gen. Franco, [b.m.], 2 XI 1943. 
także do spodziewanej fali aresztowań oficerów i agentów polskich tajnych służb wojskowych oraz funkcjonariuszy nielegalnej ewakuacji, których poza jednym wyjątkiem - oficera wywiadu, rtm. Romana Koperskiego, którego oskarżono o szpiegostwo także przeciw Hiszpanii we współpracy ze skrajnie lewicowymi „czerwonymi” - wkrótce wypuszczono na wolność i wydalono z Hiszpanii ${ }^{35}$.

Ostatecznie udało się utrzymać Poselstwo RP w Madrycie, choć działało ono odtą $\mathrm{w}$ formule nieoficjalnej. Po otrzymaniu pierwszej z marcowych not Szumlakowski - posiadajacy dobre rozeznanie w naciskach niemieckich i alianckich na Hiszpanów - zintensyfikował swoje działania mające na celu spowodowanie zaniechania wykonania zarządzeń MAE ${ }^{36}$. Dzięki licznym interwencjom rząd hiszpański zgodził się na pozostawienie w charakterze dyplomatycznym z całego składu Poselstwa RP tylko posła, ale „bez prawa urzędowania", choć w praktyce, pomimo zamknięcia placówki, polski dyplomata nadal nia de facto kierował - jak pisał ks. Antoni Liedtke - „nie molestowany przez władze hiszpańskie”. Polski kapłan zanotował w swym pamiętniku wojennym na podstawie relacji zaprzyjaźnionego urzędnika hiszpańskiego, że to minister Serrano Suñer wydał polecenie, by „nie nękać polskiego ministra [no molestar al ministro de Polonia]". Szef dyplomacji zastrzegł jednak, iż Szumlakowski nie mógł zajmować się sprawami polskimi, a szczególnie opieką nad swoimi rodakami w Mirandzie ${ }^{37}$. Co ważne, nie zażądano zdjęcia godła z balkonu budynku poselstwa, flaga dalej powiewała na maszcie, usunięto jedynie tablicę $\mathrm{z}$ godzinami urzędowania, pozostawiając główny szyld z nazwą urzędu.

Szumlakowski mógł zostać w Hiszpanii przede wszystkim dzięki nuncjuszowi apostolskiemu abp. Gaetanowi Cicognaniemu, z którym pozostawał w doskonałych stosunkach i do którego zwrócił się o wsparcie w pierwszym rzędzie. Bardzo ważne były interwencje przełożonego generalnego Towarzystwa Jezusowego o. Włodzimierza Ledóchowskiego. Pomogły także działania sekretarza stanu ds. (ministra) spraw zagranicznych Wielkiej Brytanii Anthony'ego Edena, jej ambasadora Sir Samuela Hoare'a oraz rozległe osobiste stosunki Polaka, który zaświadczał, że ostateczna decyzja w wyniku

35 J.S. Ciechanowski, Działalność..., s. 220-221; AGMAE, leg. R. 1263, exp. 13, Dyrekcja Generalna Polityki Zagranicznej MAE do DGS, Madrid, 13 X 1943.

${ }^{36}$ KMS, Szumlakowski do Raczyńskiego, [b.m.], 1 V 1942 i Madryt, 6 XI 1942.

${ }^{37}$ Archiwum Diecezjalne w Pelplinie, Dział Akt Personalnych i Spuścizn, Spuścizna ks. inf. dr. Antoniego Liedtkego, ks. dr Antoni Liedtke, Pamiętnik Wojenny, t. IX (19 II 1942); Ks. A. Liedtke, Prawda o polskich żotnierzach internowanych $w$ Miranda de Ebro, w: Kościót katolicki na ziemiach Polski w czasie II wojny światowej, t. VII: Materiaty $i$ studia, z. 3, red. ks. F. Stopniak, Warszawa 1978, s. 370, 372; AIPMS, MSW, A.9.VI.10/1, Z. Zawadowski, przedstawiciel wywiadu MSW, do J. Libracha, szefa Centralnego Biura Akcji Kontynentalnej, Lizbona, 4 V i 19 VII 1942; PA AA, RAV Madrid, 796, memorandum ANM do MAE, Madrid, 9 IX 1942. Podobnie zachowały szyld, maszt z flagą oraz godło poselstwa Jugosławii i Norwegii. 
licznych wstawiennictw „oparła się o generała Franco"38. Poseł RP ostatecznie zatrzymał w Madrycie, bez formalnej zgody hiszpańskiego MSZ, sekretarza poselstwa Eugeniusza Kobyłeckiego oraz attaché honorowego księcia Augusta Czartoryskiego, pomimo nacisków ambasadora niemieckiego, by wszyscy polscy dyplomaci wyjechali z Hiszpanii. Miejscowe władze tolerowały także załatwianie spraw konsularnych, w tym paszportowych, oraz opiekę nad Polakami w Mirandzie, sprawowana poprzez Delegaturę Polskiego Czerwonego Krzyża (PCK), uznawaną cały czas przez Hiszpański Czerwony Krzyż. Ostatecznie nie przekazano więc opieki nad polskimi interesami placówkom Wielkiej Brytanii albo Chile, co wcześniej planowano w przypadku konieczności opuszczenia Hiszpanii przez wszystkich polskich dyplomatów ${ }^{39}$.

Gdy sytuacja była już częściowo opanowana, 3 IV 1942 r. Poselstwo RP odpowiedziało hiszpańskiemu MSZ na marcowe komunikacje notą werbalna. Stwierdzano, że nie znano powodów, które mogły motywować stanowisko ministerstwa z 6 marca, po przysłaniu w lutym nowej listy korpusu. Zwracano uwagę, że stosunki dyplomatyczne pomiędzy dwoma państwami katolickimi i przyjacielskimi istniały od pięciu wieków, a Hiszpania nigdy nie uznała rozbiorów Polski. Nawoływano do uniknięcia „odpowiedzialności przed Historią z powodu tak poważnego postanowienia", gdyby doszło do ich zerwania. Przypominano o udzieleniu azylu w czasie wojny domowej, szczególnie zaś hiszpańskim oficerom, którym po ewakuacji do Polski ułatwiono przejazd do Hiszpanii „narodowej”. Podkreślano, że główną troską poselstwa byli polscy uchodźcy polityczni, internowani w obozie w Miranda de Ebro, o których zwolnienie i ewakuację do Ameryki Południowej zabiegano. W związu z tym konstatowano, że trudno było uważać za zakończoną misję humanitarna przedstawicielstwa RP wobec internowanych uchodźców ${ }^{40}$. Również i na tę notę nie otrzymano odpowiedzi ${ }^{41}$.

Postępowanie Szumlakowskiego było bardzo zręczne. Zdeterminowany, by za wszelka cenę ratować bilateralne relacje, wykorzystał fakt, że nie wezwano go ostentacyjnie do MAE i nie oświadczono w kategorycznej formie, że członkowie poselstwa z nim na czele mają opuścić Hiszpanię oraz że stosunki dyplomatyczne zostały zerwane. Ponadto polski dyplomata częściowo

${ }^{38}$ Korespondencja: AGMAE, leg. R. 2221, exp. 20; The National Archives, Kew, Richmond, Surrey, Londyn (dalej: TNA), Records created or inherited by the Foreign Office, General Correspondence from Political and Other Departments, Political Departments: General Correspondence from 1906-1966 (dalej: FO), 371/31259, Hoare do FO, Madrid, 31 III 1942; KMS, Szumlakowski do Raczyńskiego, [b.m.], 1 V 1942; J. Sobczak, Polska w propagandzie $i$ polityce III Rzeszy w latach 1939-1945, Poznań 1988, s. 84.

${ }^{39}$ KMS, nota werbalna PRPM do MAE, Madrid, 24 III 1942; notatka Szumlakowskiego, [b.m.d.]; ibidem, Szumlakowski do Raczyńskiego, [b.m.], 1 V 1942; ibidem, Raczyński do Szumlakowskiego, [b.m.], 19 V 1942.

${ }^{40}$ Ibidem, nota werbalna PRPM do MAE, Madrid, 3 IV 1942; ibidem, nota werbalna MAE do PRPM, Madrid, 16 II 1942.

${ }^{41}$ AGMAE, leg. R. 2221, exp. 20, nota werbalna PRPM do MAE, Madrid, 3 IV 1942; KMS, projekt memorandum PRPM do gen. Jordany, [b.m.d.]. 
realizował zalecenia noty z 21 stycznia. Nie oglądał się na niektóre chaotyczne i niezbyt trafne decyzje swojej niedoinformowanej centrali w Londynie, z których później ta ostatnia musiała się wycofywać. Postanowił poświęcić tymczasowo konsulaty, w gruncie rzeczy najbardziej podejrzane o prowadzenie działalności szpiegowskiej i ewakuacyjnej. W rezultacie doszło - jak się później okazało - do czasowego zawieszenia de facto stosunków dyplomatycznych między Hiszpanią i Polską. Praktycznie podchodzący do swych interesów Hiszpanie wytworzyli sytuację, w której trudno stwierdzić, czy z punktu widzenia prawa istniały, czy też nie w Madrycie placówki okupowanych państw alianckich. Wobec silnego nacisku niemieckiego rząd gen. Franco znalazł wyjście z sytuacji, które nie miało najprawdopodobniej precedensu $\mathrm{w}$ historii dyplomacji, gdyż różnie można było sobie hiszpańskie zarządzenia tłumaczyć, a decyzje na papierze zderzały się z dość skomplikowanym stanem faktycznym i ogólnym zamieszaniem.

W drugiej połowie $1942 \mathrm{r}$. Szumlakowski działał intensywnie na rzecz przywrócenia stosunków dwustronnych. Duże nadzieje wiązano ze zmiana sytuacji na frontach oraz z ponownym objęciem 3 września teki szefa dyplomacji przez dobrego znajomego polskiego dyplomaty, gen. Francisco Gómeza-Jordanę y Souzę, hrabiego Jordanę, który zastapił Serrano Suñera ${ }^{42}$. W listopadzie Szumlakowski informował centralę, że z przedstawicieli państw okupowanych przez Niemcy tylko on i poseł holenderski widzieli się z nowym ministrem ${ }^{43}$. Hiszpan wyraził wobec Polaka ubolewanie i dezaprobate dla posunięć swojego poprzednika w stosunku do Poselstwa $\mathrm{RP}^{44}$.

W tym czasie Niemcy bezskutecznie domagali się w licznych notach werbalnych i memorandach ostatecznego zamknięcia przedstawicielstw „pseudo-rządów” Polski, Jugosławii i Norwegii w Madrycie, teoretycznie już nieczynnych ${ }^{45}$. Nie ulega wątpliwości, że w przypadku polskiej placówki nacisk ze strony Berlina na Hiszpanów musiał być najsilniejszy. Hiszpańska polityka zagraniczna powoli zaczęła przybierać nowy kurs, szczególnie zaś po lądowaniu aliantów w Afryce Północnej, klęskach Wehrmachtu pod Stalingradem i Al-Alamajn. W pierwszej połowie 1943 r. Hiszpanie wypuścili Polaków i innych aliantów z obozu w Mirandzie oraz z więzień przepełnionych w wyniku masowego exodusu przede wszystkim Francuzów za Pireneje po

${ }^{42}$ KMS, Szumlakowski do Raczyńskiego, Madryt, 6 XI 1942; AIPMS, MSW, A.9.VI.10/1, Zawadowski do Libracha, Lizbona, 4 VIII 1942; ibidem, A.9.VI.10/2, K. Kraczkiewicz, przedstawiciel wywiadu MSW, do Libracha, 14 X 1943; F. Gómez-Jordana Souza, Milicia y diplomacia. Diarios del Conde de Jordana 1936-1944, selección y glosas R. Gómez-Jordana Prats, Burgos 2002, s. 174-175; R. Serrano Suñer, op. cit., s. 364-372; Rt. Hon. Sir S. Hoare, D.C.L., L L. D., D. Litt., Viscount Templewood, Ambassador on Special Mission, London 1946, s. 164-171.

${ }^{43}$ KMS, Szumlakowski do Raczyńskiego, Madryt, 6 XI 1942.

${ }^{44}$ Ibidem, Szumlakowski do Raczyńskiego, [b.m.], 25 VI 1943.

${ }^{45}$ PA AA, RAV Madrid, 796, noty werbalne ANM do MAE, Madrid, 26 V, 9 IX, 20 XI 1942. 
zajęciu przez Niemców strefy nieokupowanej Francji. Umożliwiono im następnie wyjazd z Hiszpanii. Hitlerowskim niepowodzeniom na froncie towarzyszyła także sprzyjająca wznowieniu polsko-hiszpańskich relacji koniunktura, która pojawiła się po zaostrzeniu i zerwaniu stosunków polsko-sowieckich w kwietniu 1943 r. w wyniku odkrycia w Katyniu przez Niemców masowych grobów zamordowanych przez Sowietów ok. 4,4 tys. polskich oficerów, jeńców wojennych. Prasa hiszpańska jako jedyna w Europie w sposób tak szczegółowy i obiektywny informowała o tej zbrodni ludobójstwa ${ }^{46}$. Pozytywem we wzajemnych relacjach było również to, iż w końcu nie doszło do bezpośrednich starć Niebieskiej Dywizji z Armią Polską w ZSRS, gdyż tę ostatnia udało się ewakuować do Iranu w 1942 r. Swoją rolę odgrywały także łączące Hiszpanów i Polaków katolicyzm i antykomunizm. Decydujace były jednak klęski niemieckie na frontach, czyniące zwycięstwo III Rzeszy coraz mniej prawdopodobnym, a także narastające żądania brytyjskie i amerykańskie wobec Hiszpanii, by wywiązywała się ona ze swej neutralności, poparte odpowiednim naciskiem gospodarczym.

W takiej sytuacji nastapiło wznowienie stosunków pomiędzy polską placówką a hiszpańskim MSZ. W rezultacie poufnych zabiegów posła Szumlakowskiego w sprawie przywrócenia pełnych praw Poselstwu RP, w czerwcu i lipcu 1943 r. przeprowadził on oficjalne rozmowy w Palacio de Santa Cruz, siedzibie MAE, z podsekretarzem stanu Panem de Soraluce ${ }^{47}$ oraz z dyrektorem generalnym Polityki Zagranicznej ministrem pełnomocnym José María Doussinague y Teixidorem. Były to pierwsze od wiosny poprzedniego roku oficjalne wizyty Szumlakowskiego w MAE. Podczas tych rozmów drugi z wymienionych Hiszpanów zapewnił o przyjaźni ze strony Madrytu dla polskiego rządu oraz o poparciu rekonstrukcji niepodległej Polski jako czynnika niezbędnego dla utrzymania pokoju w Europie. 28 czerwca przywrócono, formalnie zawieszoną w marcu poprzedniego roku, korespondencję urzędową między miejscowym MSZ a posłem RP - Polak otrzymał od Doussinague oficjalne pismo. 13 lipca Szumlakowski złożył hiszpańskiemu dyplomacie aide-mémoire w sprawie pełnego wznowienia stosunków oraz przywrócenia wszystkich praw polskiemu posłowi. Powoływał się m.in. na fakt, że hiszpańskie MSZ przywróciło oficjalną korespondencję z Królewskim Poselstwem Norwegii oraz reaktywowało stosunki konsularne między obydwoma państwami. Polak stwierdzał, że „nie wydaje się, by istniał jakikolwiek powód”, dla którego nie można by tego uczynić $\mathrm{w}$ odniesieniu do polskiego poselstwa ${ }^{48}$.

${ }^{46}$ Zob. korespondencję oraz wycinki prasowe: KMS; AIPMS, MSW, A.9.VI.10/1, L. As. Leonardów, przedstawiciel wywiadu MSW, raport, Madryt, 23 IV 1943. W przedstawianych madryckim władzom notach Szumlakowski wykorzystywał argument o zerwaniu stosunków polsko-sowieckich (korespondencja: KMS).

${ }^{47}$ Pełnił tę funkcję od 17 X $1942 \mathrm{r}$.

${ }^{48}$ KMS, Doussinague do Szumlakowskiego, Madrid, 28 VI 1943; ibidem, Pro memoria PRPM, [b.m.d.]; por. AIPMS, MSW, A.9.VI.10/1, Leonardów, raport, Madryt, 11 VI 1943; ibidem, 
Wszystko wskazywało na to, że normalizacja polsko-hiszpańskich relacji jest na dobrej drodze, tym bardziej że posłowi RP powoli przywracano przywileje, w tym zwolnienie od cła dla samochodów (w lipcu), przydział żywności (we wrześniu) oraz prawo szyfru (w listopadzie) ${ }^{49}$. W tym czasie polski dyplomata $\mathrm{w}$ przesłanym gen. Jordanie memorandum pisał, że stosunki dyplomatyczne między obydwoma krajami nadal istniały. Szumlakowski zręcznie nie przyjmował do wiadomości faktu ich zawieszenia, gdyż nie zostało to ustalone w żadnej oficjalnej formie. Stwierdzał, że na ostatnią notę poselstwa z 3 IV 1942 r. nigdy nie uzyskano odpowiedzi ${ }^{50}$, umiejętnie zachęcając tym samym hiszpańskiego ministra do wystosowania takiego dokumentu, co można byłoby uznać za powrót do normalnych relacji.

Tymczasem rząd RP na emigracji w nowym składzie, po śmierci w katastrofie lotniczej w Gibraltarze w lipcu 1943 r. premiera i naczelnego wodza gen. Władysława Sikorskiego, postanowił we wrześniu tego roku odwołać Szumlakowskiego ze stanowiska posła w Madrycie. Było to już zadecydowane w 1941 r. przede wszystkim w wyniku wewnętrznych polskich sporów o układ Sikorski-Majski, aczkolwiek powstrzymywano się z tym z uwagi na fakt, że Hiszpanie nie przyjmowali - podobnie jak inne kraje neutralne - nowych szefów misji państw okupowanych. Nowy gabinet, nie zważając na dobro stosunków polsko-hiszpańskich, odwołał Szumlakowskiego. Ten uznał decyzję za absurdalna, jako że zapadła ona w trakcie normalizowania relacji z Madrytem. Zawiadomił polskie MSZ, że nie ma komu przekazać placówki, gdyż oddanie jej w ręce nieuznawanego przez Hiszpanów Kobyłeckiego równałoby się jej likwidacji. W tym czasie przedstawiciele MAE dawali jasno do zrozumienia, że - zgodnie z przyjęta wobec państw okupowanych praktyka - nowego posła ani nawet chargé d'affaires w ogóle nie przyjma. W następstwie powrotu Hiszpanii do pełnej neutralności w wyniku przemówienia gen. Franco 1 X 1943 r., 18 następnego miesiąca hiszpański resort przywrócił oficjalną korespondencję z Poselstwem RP, co de facto oznaczało wznowienie stosunków dyplomatycznych. W grudniu 1943 r. próbował przejąć nieudolnie placówkę pełnomocnik ministra spraw zagranicznych Władysław Radziwiłł, oficjalnie delegat PCK. W wyniku jego działań doszło do powstania drugiej, konkurencyjnej polskiej misji na czele z Kobyłeckim, używajacej miana Poselstwa RP, aczkolwiek nieuznanej ani przez władze hiszpańskie, ani przez ambasadę brytyjska, nie mówiąc o korpusie dyplomatycznym. Jednakże sekretarz poselstwa nie używał tytułu chargé d'affaires. Odwołaniu Szumlakowskiego przeciwni byli

A.9.VI.10/2, placówka wywiadu MSW, Sprawozdanie polityczne za m. listopad 1943 r., Madryt, 30 XI 1943.

${ }^{49}$ KMS, Szumlakowski do Raczyńskiego, Madryt, 11 VI 1943; ibidem, Szumlakowski do MSZ, [b.m.], 2 VII 1943; ibidem, notatka Szumlakowskiego, [b.m.d.]; ibidem, Szumlakowski do

T. Romera, ministra spraw zagranicznych, [b.m.], 8 IX i 14 XI 1943.

${ }^{50}$ Ibidem, Szumlakowski do gen. Jordany, Madrid, IX 1942 i w zał.: memorandum PRPM do MAE, [b.m.d.]; ibidem, projekt memorandum PRPM do gen. Jordany, [b.m.d.]. 
nuncjusz apostolski w Hiszpanii oraz ambasadorzy brytyjski i amerykański. Przedstawiciele MAE wyrażali nieoficjalnie zdziwienie. Zamieszanie trwało do marca 1944 r., gdy w wyniku pobytu w Madrycie ministra Wacława Babińskiego, kolejnego delegata szefa polskiej dyplomacji, załagodzono spór posła z MSZ oraz ustalono, że zastapi go osoba w charakterze uznanego przynajmniej półoficjalnie przez Hiszpanów chargé d'affaires. W wyniku tych uzgodnień Szumlakowski rozpoczął zdawanie agend placówki ${ }^{51}$.

Ostatecznie na stanowisko nieformalnego kierownika misji został wyznaczony hr. Józef Potocki, doświadczony dyplomata, zięć księcia Janusza Radziwiłła, przed wojna wicedyrektor Departamentu Polityczno-Ekonomicznego i naczelnik Wydziału Zachodniego MSZ, akredytowany w Lizbonie jako radca poselstwa, któremu niewątpliwie zawierucha wojenna uniemożliwiła objęcie jednej z najważniejszych placówek dyplomatycznych RP. Władze hiszpańskie przyznały mu dyplomatyczną wizę docelową jako ministrowi pełnomocnemu $\mathrm{RP}$, desygnowanemu na chargé d'affaires polskiej placówki. Nastapiło to po kilkumiesięcznych zabiegach o uregulowanie sytuacji, a ostateczny polski kandydat był trzeci z kolei. Powód zamieszania stanowiły także ograniczenia komunikacyjne z Londynem, związane ze zbliżającą się aliancką inwazją na kontynent $\mathrm{w}$ Normandii. Hiszpanie z kolei nie odpowiedzieli w tej kwestii na piśmie na dwie polskie noty werbalne przekazane im w Londynie za pośrednictwem ich ambasady, próbujac całą sprawę załatwić nieformalnie ${ }^{52}$.

Upór Szumlakowskiego, choć posiadał znamiona buntu przeciwko własnemu rządowi, pozwolił na uratowanie polskiej misji w Madrycie ${ }^{53}$. Hiszpanie uznawali jego urzędowanie do czasu objęcia placówki przez Potockiego ${ }^{54}$. Ten zaś przybył do stolicy Hiszpanii 8 VI 1944 r. i dwa dni później staną na czele poselstwa jako chargé d'affaires. Szumlakowski zaprzestał urzędowania i powiadomił o zmianie kierownika placówki miejscowe MSZ i korpus. Potocki zgodnie z ostrzeżeniami Hiszpanów - nie obją jednak swej funkcji oficjalnie, nie przewidziano bowiem - pomimo polskich staran - formalnego przyjęcia go w MAE i złożenia przez niego listów przedstawiających (gabinetu), które zgodnie z protokołem powinien przekazać. Miało to swoje praktyczne skutki. Polak nie został zaproszony m.in. na pogrzeb zmarłego w sierpniu tego roku szefa hiszpańskiej dyplomacji, gen. Jordany. Potocki otrzymał jednak przywileje dyplomatyczne, będąc traktowanym jako tymczasowy kierownik Poselstwa

\footnotetext{
${ }^{51}$ Ibidem, nota werbalna MAE do PRPM, Madrid, 18 XI 1943 (była to odpowiedź na notę z 27 X); ibidem, Szumlakowski do Babińskiego, Madryt, 2 i 7 III 1944; ibidem, Szumlakowski do W. Raczkiewicza, prezydenta RP, Madryt, 15 XII 1943; ibidem, Diariusz Mariana Szumlakowskiego 1940-1944, rkps, 4 I 1944; TNA, FO 371/31259, A. Cadogan, stały podsekretarz stanu ds. zagranicznych, do Hoare'a, [London], 14 XI 1942.

${ }^{52}$ Zob. korespondencję: AIPMS, PM, A.45.599/2.

${ }^{53}$ Zob. J.S. Ciechanowski, Szumlakowski Marian (1893-1961), dyplomata, w: Polski Stownik Biograficzny (dalej: PSB), t. XLIX/3, z. 202, Warszawa-Kraków 2014, s. 332-336.

${ }^{54}$ AGMAE, leg. R. 3510, exp. 7, Nuestras relaciones.
} 
RP w Madrycie. Wydano mu legitymację członka Korpusu Dyplomatycznego tamże z zaznaczeniem tytułu i funkcji (,el Excmo. Señor Ministro Conde Józef Potocki, [...] Encargado de Negocios de Polonia”, czyli „J.E. Pan Minister Hrabia Józef Potocki, [...] Chargé d'affaires Polski”) ${ }^{55}$. Już od wznowienia korespondencji z polska placówką MAE podtrzymywało z nią normalne stosunki, jego urzędnicy brali udział w organizowanych przez Polaków uroczystościach, a w maju 1944 r., pierwszy raz od 1940 r., władze hiszpańskie uznały polskiego kuriera dyplomatycznego ${ }^{56}$.

Wszystko to w przypadku zakończenia wojny i odzyskania przez Polskę niepodległości pozwoliłoby na normalne wznowienie relacji i akredytowanie pełnomocnych przedstawicieli. Jednak pozycja międzynarodowa rządu RP na uchodźstwie słabła wraz ze wzrostem znaczenia w koalicji Sowietów oraz przede wszystkim wkroczeniem Armii Czerwonej na ziemie polskie i jej dalszym pochodem na zachód Europy, co było także zagrożeniem dla reżimu hiszpańskiego. Po cofnięciu uznania rządowi RP na uchodźstwie przez mocarstwa zachodnie w lipcu 1945 r., władze hiszpańskie zachowały się życzliwie i nie wycofały oficjalnie polskiemu gabinetowi uznania, jak miało to miejsce $\mathrm{w}$ Lizbonie, gdzie podczas wojny zachowano normalne stosunki dyplomatyczne ${ }^{57}$. Nawiązanie ich z komunistyczną Polską było wykluczone. 11 lipca polski minister pisał do Anny Rodón, delegata PCK w Barcelonie, że „stanowisko władz hiszpańskich wobec naszego przedstawicielstwa nie uległo zmianie" ${ }^{58}$. Poselstwo RP w Madrycie istniało nadal, choć jego personel zredukowano. Było kurtuazyjnie uznawane jako placówka „półoficjalna” (oficiosa), zajmujacca się m.in. opieką nad polskimi uchodźcami ${ }^{59}$. Podobnie funkcjonowały tego rodzaju przedstawicielstwa Węgier, Czechosłowacji, Słowacji, Jugosławii, Bułgarii i Rumunii, a większość ich szefów cieszyła się - jak

55 Spuścizna Józefa hr. Potockiego, Madryt, MAE, Tarjeta de identidad para miembros del Cuerpo Diplomático, Józef Potocki, Madrid, 1 VII 1944 (autor składa wyrazy podziękowania panu Piotrowi hr. Potockiemu za udostępnienie tego dokumentu).

${ }^{56}$ Korespondencja: AIPMS, PM, A.45.599/2; KMS; AGMAE, leg. R. 5787, exp. 6; ibidem, leg. P. 376, exp. 271421; T. Wyrwa, Przedstawiciel „Wolnej Francji” w Hiszpanii o zmianach w poselstwie polskim w Madrycie w 1944 roku, „Zeszyty Historyczne” 1988, z. 84, s. 217-219; J. Łobodowski, „Tu mówi Madryt”, „Zeszyty Historyczne” 1980, z. 54, s. 120-121. Placówka polskiego wywiadu cywilnego MSW w Madrycie donosiła do Londynu, że gen. Jordana miał oświadczyć jednemu z ambasadorów państw sprzymierzonych, iż hiszpański gabinet zamierza mianować przedstawiciela przy rządzie polskim. AIPMS, MSW, A.9.VI.10/2, notatka Akcji Kontynentalnej MSW, Wiadomości z Hiszpanii, Madryt, 23 XI 1943. Nie udało mi się znaleźć potwierdzenia tego faktu w źródłach hiszpańskich.

57 S. Schimitzek, Na krawędzi Europy. Wspomnienia portugalskie 1939-1946, Warszawa 1970, s. 704.

58 AIPMS, PM, A.45.474/13, Potocki do Rodón, Madryt, 11 VII 1945.

${ }_{59}$ Zob. archiwum PRPM w latach 1945-1968: ibidem, A.45; por. AGMAE, leg. R. 3510, exp. 7, Nuestras relaciones; ibidem, leg. R. 1771, exp. 63, podsekretarz stanu w MAE do dyrektora generalnego ceł, Madrid, 28 IX 1945; W. Michowicz, Organizacja polskiej stużby dyplomatycznej w okresie II wojny światowej, w: Historia dyplomacji polskiej..., t. V, s. 79. 
Potocki - częścią przywilejów dyplomatycznych, m.in. celnych, oraz prawem do używania plakiety CD na samochodach ${ }^{60}$.

Charakterystyczna pod tym względem jest notatka MAE na temat stosunków polsko-hiszpańskich w latach 1936-1946. Opracowujący ją hiszpański dyplomata skonstatował, że gdy mocarstwa uznały rząd polski w Warszawie, Potocki reprezentował odtąd tylko „rząd-fantazmę”, który nadal istniał w Londynie, gdzie jego członkowie byli traktowani jako „wybitni obcokrajowcy" ${ }^{61}$. Madryckie władze z życzliwością patrzyły więc na działalność placówek reprezentujących narody „ujarzmione przez komunizm”, które z czasem znalazły się za ,żelazną kurtyna”. Utrzymywanie normalnych stosunków dyplomatycznych było jednak niemożliwe. Polskie poselstwo nie pojawiło się już na oficjalnych listach akredytowanego w Madrycie korpusu dyplomatycznego, a Potocki nie został ujęty w precedencji chargé d'affaires en pied ${ }^{62}$. Stanowi to główny i formalny dowód na brak oficjalnych relacji. Stan z lat 1943-1945 Hiszpanie traktowali jako tymczasowy, oczekując na wyjaśnienie sytuacji. Utrata przez Polskę niepodległości stała się trwałym skutkiem napaści niemiecko-sowieckiej z września 1939 r., a polski gabinet pozbawiony był władzy nad terytorium państwa.

Główną przyczynę generalnie negatywnego stosunku Madrytu do rządów na uchodźstwie - jak wyraźnie wynika z dokumentacji hiszpańskiego MSZ - stanowiła jednak możliwość powołania tego rodzaju ciała ze strony hiszpańskiej lewicy na emigracji. Słyszało się o tym już w czasie wojny. Tak też stało się w sierpniu 1945 r., gdy w Meksyku powołano rząd republikański na czele z José Giralem, od lutego 1946 r. z siedzibą w Paryżu. 4 kwietnia tego roku gabinet ten został uznany przez Polskę komunistyczną i nawiazał z nią stosunki dyplomatyczne ${ }^{63}$. Biuro Informacji Dyplomatycznej MAE wydało oświadczenie, w którym pisano o tym, iż rząd hiszpański nie uznał gabinetu narzuconego w wyniku okupacji sowieckiej Polski, a „kuriozalne uznanie pseudo-rządu bez terytorium, obywateli ani realnej władzy, w niczym nie może umniejszyć [...] tradycyjnej sympatii Hiszpanii dla katolickiego narodu polskiego" ${ }^{64}$. W tym czasie reżim gen. Franco toczył walkę o zabezpieczenie się przed skutkami wymierzonej w niego nagonki. Oficjalnie na

${ }^{60}$ M. Eiroa, Las relaciones de Franco con Europa Centro-Oriental (1939-1955), Barcelona 2001, s. 103-148; K.S. Gyuricza, P. Gyuricza, Ferenc Marosy. Un embajador real de Hungría en Madrid (1949-1969) / Marosy Ferenc. Egy magyar király követ Madridban (1949-1969), Budapest 2017, s. 45-191.

${ }^{61}$ AGMAE, leg. R. 3510, exp. 7, Nuestras relaciones.

62 Zob. Lista del Cuerpo Diplomático, Madrid 1948, 1949, 1950, 1951, 1952, 1953, 1954.

${ }^{63}$ M. Eiroa, op. cit., s. 85-86; J.S. Ciechanowski, Las relaciones entre la Polonia comunista y la República española en el exilio. Razones políticas de la misión de Manuel Sánchez Arcas en Varsovia (1946-1950), „Ayer” (Madrid) 2007, nr 3 (67), s. 54-55.

${ }^{64}$ España no reconoció nunca al Gobierno de Varsovia. El acto de ese instrumento de los soviets en nada disminuye nuestra simpatía por el pueblo polaco, „ABC. Diario ilustrado de información general”, (Madrid) 9 IV 1946, s. 15. 
czele tej kampanii na forum ONZ stała satelicka Polska komunistyczna, która reprezentował Oskar Lange, jak się okazało w wyniku amerykańskiej operacji „Venona”, agent sowiecki o pseudonimie Friend ${ }^{65}$. Hiszpania starała się uniknać izolacji oraz przede wszystkim ewentualnej interwencji zbrojnej zwycięskich mocarstw alianckich, w tym Związku Sowieckiego, który wraz z międzynarodowym komunizmem, wspieranym przez siły socjalistyczne, dążył do obalenia siłą dyktatury madryckiej jako sojuszniczki Hitlera w czasie wojny. W celu przejęcia władzy hiszpańscy komuniści zamierzali powtórzyć manewr zastosowany przez Stalina w Europie Środkowo-Wschodniej ${ }^{66}$.

Skoro formalne stosunki dyplomatyczne między Polską niepodległa a Hiszpanią nie istniały po II wojnie światowej, należy postawić pytanie, skąd wzięła się teza, że było inaczej? Wynikało to z wielu czynników. Nie wycofano oficjalnie uznania rządu ani Poselstwa RP, to ostatnie traktowano kurtuazyjnie, a jego kierownik utrzymał część przywilejów dyplomatycznych. Hrabia Potocki funkcjonował w hiszpańskim towarzystwie jako „ministro de Polonia”, wobec czynników polskich używając wewnętrznego tytułu posła RP, na które zreszta stanowisko został oficjalnie mianowany ${ }^{67}$. Dzięki niemu pozycja polskiej placówki była szczególna. Niemałą rolę odgrywały jego arystokratyczne, towarzyskie i zawodowe koneksje. Poselstwo RP prowadziło ożywioną działalność polityczna, kulturalną i propagandowa. Z MAE utrzymywano korespondencję przede wszystkim w sprawach konsularnych. Na zewnątrz, w ramach życia towarzyskiego Madrytu oraz w miejscowej prasie, misja funkcjonowała tak, jakby jej status był jak najbardziej oficjalny ${ }^{68}$.

W samym Madrycie przez wiele lat nikt nie protestował przeciwko istnieniu polskiej placówki. Gdy w latach 1955-1961, w wyniku rozłamu na emigracji, funkcjonowały dwa Poselstwa RP w Madrycie, kierowane przez reprezentującego Radę Trzech Potockiego oraz prezydenta i rząd RP Szumlakowskiego, Hiszpanie nie reagowali, nie chcąc naruszać status quo, a obydwaj polscy dyplomaci byli traktowani jako przedstawiciele polskich sił

${ }^{65}$ Polsko-Brytyjska wspótpraca wywiadowcza podczas II wojny światowej / Intelligence Co-operation Between Poland and Great Britain During World War II, t. II: Documents, wybór i red. J.S. Ciechanowski, Warszawa 2005, s. 290; J.E. Haynes, H. Klehr, Venona. Decoding Soviet Espionage in America, New Haven-London 1999, s. 234-236; H. Romerstein, E. Breindel, The Venona Secrets. Exposing Soviet Espionage and America's Traitors, Washington 2000, s. 416-417.

${ }^{66}$ Archiwum Ministerstwa Spraw Zagranicznych w Warszawie, Departament Polityczny, akta za lata 1945-1948 (zespół 6), teczka 1019, wiązka 73, S. Skrzeszewski, ambasador w Paryżu, do Z. Modzelewskiego, wiceministra spraw zagranicznych, Paryż, 11 IV 1946; J.S. Ciechanowski, Las relaciones..., s. 55.

${ }^{67}$ KMS, Szumlakowski do A. Bobkowskiego, Madryt, 18 III 1958; Diariusz i Teki Jana Szembeka (1935-1945), t. I, oprac. T. Komarnicki, Londyn 1964, s. 584.

${ }^{68}$ Zob. korespondencję: AIPMS, PM, A.45; Wielki świat, wielka polityka 1940-1951. Korespondencja Józefa Potockiego i Alika Koziett-Poklewskiego, oprac. i komentarze J. Jakubowicz, Kraków 2015. 
niepodległościowych, choć z natury rzeczy ta pierwsza placówka odgrywała większą rolę ${ }^{69}$. W emigracyjnej dokumentacji urzędowej znajdujemy więc liczne potwierdzenia, że stosunki istniały, a poselstwo uznawano ${ }^{70}$. Nikt nie był zainteresowany, by podkreślać, że odbywało się to na dość specyficznych zasadach, że nie istniały normalne stosunki dyplomatyczne, jak choćby do 1958 r. ze Stolica Apostolską ${ }^{71}$, a polska placówka nie znajdowała się na oficjalnej liście akredytowanego w Madrycie korpusu dyplomatycznego. Tak więc w polskich kręgach emigracyjnych panowało powszechne przekonanie, że rząd gen. Franco oficjalnie uznawał po wojnie rząd RP na uchodźstwie ${ }^{72}$.

Szumlakowski otrzymywał z Londynu symboliczne środki na działanie, a siedziba poselstwa mieściła się w jego mieszkaniu. W 1959 r. został ambasadorem ad personam. Po jego śmierci w 1961 r. rząd na uchodźstwie reprezentował do swego zgonu w 1968 r. Kobyłecki. Na fali liberalizacji reżimu frankistowskiego i jego polityki zagranicznej w 1963 r. otwarto w Madrycie Biuro Delegata Polskiej Izby Handlu Zagranicznego, a w następnym roku w Warszawie - Biuro Delegata Hiszpańskiego Instytutu Walut Zagranicznych (Instituto Español de Moneda Extranjera). 12 IX 1968 r. zmarł w szwajcarskiej Lozannie minister Potocki, w wyniku czego na czele placówki reprezentującej Radę Trzech stanął prof. Antoni Deryng. Jednakże 15 lipca następnego roku Warszawa i Madryt zawarły porozumienie o przekształceniu biur delegatów w oficjalne przedstawicielstwa konsularno-handlowe. Nawiązanie stosunków konsularno-handlowych spowodowało, iż władze hiszpańskie nakazały Deryngowi usunięcie z budynku, w którym mieściła się placówka, szyldu poselstwa

${ }^{69}$ AIPMS, Akta osobowe i organizacji na uchodźstwie, Kolekcja Generała Andersa (KOL. 11), 244, A. Zawisza, minister spraw zagranicznych, do Potockiego, Londyn, 18 XI 1955; ibidem, Prezydium Rady Ministrów, Archiwum Kancelarii, 1939-1990, PRM.K./103, protokoły posiedzeń Rady Ministrów RP z 22 II i 25 VI 1968; AGMAE, leg. R. 3510, exp. 7, A. Martín-Artajo, minister spraw zagranicznych, do ambasadora Hiszpanii przy Stolicy Apostolskiej, [Madrid], 14 XI 1955; J.S. Ciechanowski, Szumlakowski Marian..., s. 335; K. Tarka, op. cit., s. 164.

70 Zob. korespondencję: AIPMS, PM, A.45; ibidem, Ministerstwo Spraw Zagranicznych, A.11.E; ibidem, Kancelaria Cywilna i Gabinet Wojskowy Prezydenta RP, 1939-1991, A.48.8/C3 cz. I, Państwa, które poza Zachodnią Półkula, nadal uznają rząd R.P. / Sytuacja w Ameryce Łacińskiej, [b.m.], 29 X 1945.

${ }^{11}$ Zob. T. Wyrwa, Likwidacja ambasady R.P. przy Watykanie w latach 1958 i 1972, „Zeszyty Historyczne” 1990, z. 93, s. 49-60; P. Machcewicz, op. cit., s. 217-218; Stolica Apostolska wobec Polski i Polaków w latach 1944-1958 w świetle materiałów ambasady RP przy Watykanie (Wybór dokumentów), oprac. J. Żaryn, Warszawa 1998, passim; Kościót w Polsce $w$ latach przełomu (1953-1958). Relacje ambasadora RP przy Stolicy Apostolskiej, oprac. J. Żaryn, Warszawa 2000, s. 6-7, 169, 183-184, 195-197, 226. Ambasadę RP przy Stolicy Apostolskiej ostatecznie zlikwidowano w wyniku decyzji Sekretariatu Stanu w 1972 r.

${ }^{72}$ KMS, R. Zilberman do Szumlakowskiego, Lizbona, 10 V 1949; E. Szczepanik, Polityka niepodległościowa władz Rzeczypospolitej Polskiej na uchodźstwie w latach 1945-1990, Londyn 1999, s. 3; J. Wyrwa, „Furgalski”, „Stary”, Pamiętniki Partyzanta, wyd. 2 popr. i uzup., Londyn 1991, s. 567, 579. 
oraz PCK. Polska misja została zlikwidowana, a jej archiwum przekazane do Instytutu Polskiego i Muzeum im. gen. Sikorskiego w Londynie ${ }^{73}$.

Zmierzająca ku demokracji Hiszpania nawiązała stosunki dyplomatyczne na szczeblu ambasad z Polską komunistyczna, zwaną „ludowa”, dopiero 31 I 1977 r., ponad rok po śmierci gen. Franco ${ }^{74}$. Utrzymano je z natury rzeczy z już wolną i demokratyczną Rzeczpospolitą Polską. 18 IX 1990 r. w Pałacu Królewskim w Madrycie ambasador RP, prof. Jan Kieniewicz, złożył listy uwierzytelniające królowi Hiszpanii Janowi Karolowi I ${ }^{75}$. Stał się tym samym pierwszym po 46 latach przerwy pełnomocnym przedstawicielem wolnej Polski przy głowie państwa hiszpańskiego, zgodnie z kanonami prawa międzynarodowego oraz praw krajowych - polskiego i hiszpańskiego.

Rekapitulując, wznowione w 1919 r. stosunki dyplomatyczne między Polska i Hiszpanią zostały de facto i nieoficjalnie zawieszone w $1942 \mathrm{r}$. W następnym roku przywrócono je w ten sam sposób, aczkolwiek bez możliwości oficjalnego akredytowania nowego kierownika polskiej placówki do zakończenia wojny. Po cofnięciu przez mocarstwa zachodnie uznania rządowi RP na uchodźstwie w lipcu 1945 r., Hiszpania utrzymywała z polskim poselstwem (a w latach 1955-1961 praktycznie $\mathrm{z}$ dwoma) relacje półoficjalne, oparte głównie na autorytecie oraz oficjalnych rangach i tytułach ich kierowników oraz finansowaniu placówek z Londynu. W latach 1945-1977 między Polska i Hiszpanią nie istniały stosunki dyplomatyczne, choć w latach 1946-1950 formalnie łączyły one kontrolowaną przez Sowietów dyktaturę warszawska oraz hiszpański lewicowy rząd republikański na emigracji.

\section{Streszczenie}

W polskich opracowaniach często przyjmuje się, że hiszpańska dyktatura gen. Francisco Franco utrzymywała pełne stosunki dyplomatyczne z rządem RP na uchodźstwie w Londynie w latach 1945-1968. W rzeczywistości jednak mamy do czynienia z mitem, choć Poselstwo RP w Madrycie, kierowane przez ministra Józefa Potockiego, mogło funkcjonować i rozwijać swoją działalność. Nie znajdowało się jednak na oficjalnej liście korpusu dyplomatycznego akredytowanego w stolicy Hiszpanii, a jego kierownik nie został ujęty w precedencji szefów misji. Było to związane także z okresem II wojny światowej, kiedy w wyniku nacisków

73 A. Szklarska-Lohmannowa, Potocki Józef Alfred (1895-1968), dyplomata, PSB, t. XXVIII/1, z. 116, Wrocław 1984, s. 82; P. Machcewicz, op. cit., s. 218; K. Tarka, op. cit., s. 164; L. Miró Liaño, M.D. Ferrero Blanco, Motivaciones y dificultades en la evolución de las relaciones económico-comerciales hispano-polacas (1950-1970), „Ayer” 2007, nr 3 (67), s. 117-118; Relaciones hispano-polacas, „ABC”, (Madrid) 16 VII 1969, s. 75-76; AIPMS, PM, A.45.

74 Stosunki dyplomatyczne Polski. Informator, t. I: Europa 1918-2006, red. K. Szczepanik, A. Herman-Łukasik, B. Janicka, Warszawa 2007, s. 185-186; Stosunki dyplomatyczne Polski 1944-1981 r. Informator, t. II: Europa, państwa kapitalistyczne, cz. 1, oprac. J. Patryas, H. Szczepaniak, Warszawa 1986, s. 325.

75 Seis nuevos embajadores presentaron ayer credenciales a Su Majestad el Rey en el Palacio Real, „ABC”, (Madrid) 19 IX 1990, s. 4. 
niemieckich oraz szeroko zakrojonej działalności polskich placówek ewakuacyjnych i wywiadowczych stosunki dyplomatyczne między Polską i Hiszpanią zostały de facto i nieoficjalnie zawieszone w $1942 \mathrm{r}$. W następnym roku przywrócono je w ten sam sposób, aczkolwiek bez możliwości oficjalnego akredytowania nowego kierownika polskiej placówki do zakończenia konfliktu. Gdy w 1944 r. zakończył swą misję zdymisjonowany poseł RP Marian Szumlakowski, hiszpańskie MSZ oficjalnie nie uznało nowego kierownika poselstwa Józefa Potockiego jako oficjalnego chargé d'affaires, co Polakom wcześniej zapowiedziano. Po cofnięciu przez mocarstwa zachodnie uznania rządowi RP na uchodźstwie w lipcu 1945 r., Hiszpania nie uczyniła tego i zaczęła utrzymywać z polskim poselstwem (a w latach 1955-1961 praktycznie z dwoma) relacje półoficjalne, oparte głównie na autorytecie oraz oficjalnych rangach i tytułach ich kierowników oraz finansowaniu placówek z Londynu. W latach 1945-1977 między Polską i Hiszpanią nie istniały stosunki dyplomatyczne, choć w latach 1946-1950 formalnie łączyły one kontrolowaną przez Sowietów dyktaturę warszawską oraz hiszpański lewicowy rząd republikański na emigracji.

\section{Recognition by Spain of the Government of the Republic of Poland in Exile in 1945-1968. The Story of a Certain Myth}

Polish studies have often assumed that the Spanish dictatorship of General Francisco Franco maintained full diplomatic relations with the Polish Government in Exile in London in 1945-1968. In reality, however, we deal with a myth, although the Polish Embassy in Madrid, headed by Minister Józef Potocki, could function and develop its activities. It was not on the official list of the Diplomatic Corps accredited in the Spanish capital, and its head was not included in the precedence of the chiefs of mission. It was also related to the period of the Second World War, when, as a result of German pressure and the extensive activity of Polish evacuation and intelligence posts, diplomatic relations between Poland and Spain were de facto and unofficially suspended in 1942. The following year, they were restored in the same way, although without the possibility of official accreditation of the new head of the Polish post until the end of the conflict. When the dismissed Polish envoy Marian Szumlakowski ended his mission in 1944, the Spanish Ministry of Foreign Affairs did not officially recognise the new head of the mission, Józef Potocki, as the official chargé d'affaires, as had been previously announced to the Poles. After the Western Powers withdrew their recognition of the Polish Government in Exile in July 1945, Spain did not do so, and began to maintain semi-official relations with the Polish legation (and, in 1955-1961, practically with two of them), based mainly on the authority and official ranks and titles of their heads and the financing of the missions from London. Between 1945 and 1977, no diplomatic relations between Poland and Spain existed, although in 1946-1950, they formally connected the Soviet-controlled Warsaw dictatorship and the Spanish left-wing republican government in exile.

\section{Bibliografia}

Ajzner S., Państwo polskie wobec wojny domowej w Hiszpanii 1936-1939, „Najnowsze Dzieje Polski. Materiały i Studia z Okresu 1914-1939” 1963, t. VI, s. 43-76.

Ajzner S., Polska a wojna domowa w Hiszpanii 1936-1939, Warszawa 1968.

Batowski H., Polska dyplomacja na obczyźnie 1939-1941, Kraków 1991.

Ciechanowski J.S., Działalność polskiego wywiadu w Hiszpanii w czasie II wojny światowej, w: Szpiegostwo, wywiad, państwo, red. C. Taracha, t. I, Lublin 2009, s. 205-241. 
Ciechanowski J.S., General Anders and His Contacts With Spain, w: General Wtadystaw Anders. Soldier and Leader of the Free Poles in Exile. Papers from the Conference Organised by the Polish University Abroad London 15-16 June 2007, red. J. Pyłat, J. Ciechanowski, A. Suchcitz, London 2008, s. 193-206.

Ciechanowski J.S., Las relaciones entre la Polonia comunista y la República española en el exilio. Razones políticas de la misión de Manuel Sánchez Arcas en Varsovia (1946-1950), „Ayer" (Madrid) 2007, nr 3 (67), s. 49-79.

Ciechanowski J.S., Pedroso y Madan, Luis de, w: Diccionario Biográfico Español, t. XL, Madrid 2010, s. 477-478.

Ciechanowski J.S., Podwójna gra. Rzeczpospolita Polska wobec hiszpańskiej wojny domowej 1936-1939, Warszawa 2014.

Ciechanowski J.S., Polscy ochotnicy po stronie narodowej $w$ czasie hiszpańskiej wojny domowej (1936-1939), w: Studia polsko-hiszpańskie. Wiek XX, red. J. Kieniewicz, Warszawa 2004, s. 117-151.

Ciechanowski J.S., Szumlakowski Marian (1893-1961), dyplomata, w: Polski Stownik Biograficzny, t. XLIX/3, z. 202, Warszawa-Kraków 2014, s. 332-336.

Drozdowski M.M., Ignacy Jan Paderewski. Zarys biografii politycznej, wyd. 3 popr. i rozsz., Warszawa 1986.

Eiroa M., Las relaciones de Franco con Europa Centro-Oriental (1939-1955), Barcelona 2001.

González Caizán C., Por Napoleón en España. Los soldados polacos en los Sitios de Zaragoza (1808-1809), Madrid 2017.

Gyuricza K.S., Gyuricza P., Ferenc Marosy. Un embajador real de Hungría en Madrid (19491969) / Marosy Ferenc. Egy magyar király követ Madridban (1949-1969), Budapest 2017.

Haynes J.E., Klehr H., Venona. Decoding Soviet Espionage in America, New Haven-London 1999.

Kaczorowski B., Churchill i Franco. Hiszpania w polityce Wielkiej Brytanii w okresie drugiej wojny światowej, Warszawa 2014.

Liedtke A. ks., Prawda o polskich żotnierzach internowanych w Miranda de Ebro, w: Kościót katolicki na ziemiach Polski w czasie II wojny światowej, t. VII: Materiaty i studia, z. III, red. ks. F. Stopniak, Warszawa 1978, s. 353-394.

Liedtke A. ks., Wojenne losy biskupa chetmińskiego Stanisława Wojciecha Okoniewskiego 1939-1944, Pelplin 1983.

Lisiak H., Paderewski. Od Kurytówki po Arlington, Poznań 1992.

Machcewicz P., Emigracja w polityce międzynarodowej, Warszawa 1999.

Michowicz W., Organizacja polskiej stużby dyplomatycznej w okresie II wojny światowej, w: Historia dyplomacji polskiej, t. V: 1939-1945, red. W. Michowicz, Warszawa 1999, s. 9-105.

Miró Liaño L., Ferrero Blanco M.D., Motivaciones y dificultades en la evolución de las relaciones económico-comerciales hispano-polacas (1950-1970), „Ayer” 2007, nr 3 (67), s. 81-118.

Perkowska-Waszek M., Ignacy Jan Paderewski o sobie. Zarys biografii wzbogacony listami artysty, Tarnów-Kaśna Dolna 2004.

Romerstein H., Breindel E., The Venona Secrets. Exposing Soviet Espionage and America's Traitors, Washington 2000.

Sobczak J., Polska $w$ propagandzie i polityce III Rzeszy $w$ latach 1939-1945, Poznań 1988.

Szczepanik E., Polityka niepodległościowa władz Rzeczypospolitej Polskiej na uchodźstwie w latach 1945-1990, Londyn 1999.

Szklarska-Lohmannowa A., Potocki Józef Alfred (1895-1968), dyplomata, w: Polski Stownik Biograficzny, t. XXVIII/1, z. 116, Wrocław 1984, s. 81-82.

Tarka K., Emigracyjna dyplomacja. Polityka zagraniczna rzadu RP na uchodźstwie 1945-1990, Warszawa 2003. 
Tebinka J., Dyplomacja popaździernikowa (1957-1960), w: Historia dyplomacji polskiej, t. VI: 1944/1945-1989, Warszawa 2010, s. 444-580.

Tochman K.A., Z ziemi obcej do Polski. Losy żotnierzy Polskich Sit Zbrojnych, którzy powrócili do kraju po II wojnie światowej, t. I, Zwierzyniec-Rzeszów-Londyn 2006.

Wyrwa T., Likwidacja ambasady R.P. przy Watykanie w latach 1958 i 1972, „Zeszyty Historyczne" 1990 , z. 93, s. 49-60.

Wyrwa T., Poselstwo R.P. w Madrycie w latach 1940-1944, „Zeszyty Historyczne” 1991, z. 95 , s. 55-72.

Wyrwa T., Przedstawiciel „Wolnej Francji” w Hiszpanii o zmianach w poselstwie polskim w Madrycie w 1944 roku, „Zeszyty Historyczne” 1988, z. 84, s. 217-219.

Jan Stanisław Ciechanowski - dr hab. nauk humanistycznych w zakresie historii; historyk i politolog. Adiunkt na Wydziale „Artes Liberales” Uniwersytetu Warszawskiego. Od 2011 r. członek-korespondent Portugalskiej Akademii Historii (Academia Portuguesa da História) w Lizbonie. Specjalista historii XX w. Zajmuje się polskim udziałem w II wojnie światowej, w tym szczególnie dyplomacją i wywiadem, dyplomacją II RP, relacjami polsko-hiszpańskimi i polsko-portugalskimi, współczesną historią regionu Morza Śródziemnego, a także dziejami Hiszpanii i Portugalii w XX w. E-mail: js.ciechanowski@uw.edu.pl.

Jan Stanisław Ciechanowski - Dr Hab. in history; historian and political scientist. Assistant professor at the Faculty of 'Artes Liberales' at the University of Warsaw. Corresponding Member of the Portuguese Academy of History (Academia Portuguesa da História) in Lisbon. Expert on the 20th-century history. He is interested in the Polish participation in World War II, especially diplomacy and intelligence, diplomacy of the Second Polish Republic, Polish-Spanish relations, contemporary history of the Mediterranean region, and the history of Spain and Portugal in the 20th century. E-mail: js.ciechanowski@uw.edu.pl. 